\title{
Perspectives in the Study of the Zoogeography of Interstitial Crustacea: Bathynellacea (Syncarida) and Parastenocarididae (Copepoda)
}

\author{
Horst Kurt Schminke*
}

SUMMARY

Aspects of the zoogeography of Bathynellacea and Parastenocarididae are discussed in the light of my recent investigations. Parastenocarididae in Australia are rare and not very diverse in number of species. Four species belonging to three genera were collected on a tour through $\mathrm{Au}-$ stralia in 1968. Despite relationships to species from other Gondwanian landmasses the poorness of the Australian fauna, together with the apparent ability of this family to spread over longer distances, suggest a late arrival of Parastenocarididae in Australia. Invasion is likely to have taken place from two directions. As for the Bathynellacea, the relationships presumed to exist between genera from Australia and Malaysia within the Parabathynellidae have been invalidated. As an alternative to the double-armed dispersal model of the Parabathynellidae propounded earlier, a vicariance model is discussed following Schram (1977). The zoogeography of Parastenocarididae can probably be best explained in terms of a primary dispersal history.

Two groups among crustaceans belong to the most characteristic elements of freshwater interstitial fauna: the Bathynellacea, an order of the Syncarida within the Malacostraca, and the Parastenocarididae, a family of the Copepoda Harpacticoidea. I have been interested in the Bathynellacea for a long time and have recently been studying the Parastenocarididae. Particular emphasis in this work has been placed on problems of historical zoogeography. Why select just these two groups for this kind of study?

\section{PARASTENOCARIDIDAE}

The Australian fauna is a good case in point to explain this. On a collecting tour through Australia in 1968, I took 45 samples of freshwater interstitial fauna in New South Wales, Victoria, Western Australia and on Tasmania (Schminke 1973, fig. 3). The sorted samples showed a surprising result. Only 13 of $45(29 \%)$ yielded Parastenocarididae species, whereas Bathynellacea were present in $20(45 \%)$ of them. The usual situation is just the opposite. In South Africa for example, 65 of 89 samples $(73 \%)$ contained species of Parastenocarididae whereas Bathynellacea were extracted from only $44(50 \%)$ of

\footnotetext{
* Fachbereich IV, Universität Oldenburg, Ammerländer Heerstr., D-2900 Oldenburg, Germany.
} 
these. In New Caledonia 34 of $52(65 \%)$ samples yielded species of Parastenocarididae whereas Bathynellacea were absent.

Equally surprising, though in agreement with the low number of samples yielding Parastenocarididae at all, was the fact that, except for one, all of the samples contained only one species. This is very poor. In New Caledonia the average was two species per sample with some samples containing four or five species. In South Africa the average was three species, with a few samples yielding as many as six or seven species. Parastenocarididae are not only rare in Australia, they are also not very diverse in the number of species. Despite the huge area sampled only four species were found.Three of them were encountered in Eastern, and a single species in Western Australia. None were found on Tasmania.

The systematics of the Parastenocarididae are still in a state that precludes far reaching conclusions as to the phylogenetic relationships of its genera. But my own extensive work during the last two years, yet to be published, has at least unveiled criteria for a clear delimitation of these genera. According to these criteria, the four Australian species can be assigned to three genera. The species from Western Australia belongs to the genus Cafferocaris, which has a great number of species and is widely distributed all along East Africa, from Kenya down to South Africa and also on Madagascar. Two of the species from Eastern Australia representing a new genús are very closely related to, if not congeneric with, species from India (material, leg. Noodt) and Sri Lanka (Enckell, 1970). The remaining species and genus cannot be classified as yet.

From these relationships it may appear that the Australian species are remnants of an old Gondwanian stock, the descendants of which are now scattered over the once interconnected continents in the southern hemisphere. But if Parastenocarididae have been in Australia for such a long time, why are they so rare? In Africa and South America, this family is virtually teeming with species. The alternative would be that Parastenocarididae are of fairly recent occurrence in Australia. Their dispersive capacity appears to be such as to allow dispersal over longer distances (Enckell, 1969; Kulhavy and Noodt, 1968). By what means this is achieved we do not know. Yet, not only have Parastenocarididae been recorded from purely volcanic islands such as Iceland (Kulhavy and Noodt, 1968), and Tenerife of the Canary Islands (Schminke, 1971), which they could not have reached by land connections, they also are not entirely interstitial in existence.Some species have been found in mosses and on the Indonesian islands in phytothelms (Chappuis, 1931).

An invasion into Australia long after the breakup of Gondwana, therefore, does not appear to be completely out of the question. The distribution of the Australian genera and their affinities to species from other continents would, on the contrary, be better explained by this hypothesis, as would what appears to be a thinning out of Parastenocarididae to the south within Australia and their probable absence from Tasmania. But confirmation is needed from additional sampling before their absence from Tasmania can be taken for granted. A late arrival in Australia of this family would also make 
less surprising their probable absence from New Zealand. About 190 samples of freshwater interstitial fauna were taken throughout New Zealand in 1967/68 (Schminke 1973, fig. 2), but no Parastenoearididae were discovered.

Current evidence, then, seems to suggest an arrival of Parastenocarididae in Australia after the rupture of the Gondwanian landmass. It is impossible to give even a rough estimate for the probable date of this arrival. One reason is that the invasion seems to have taken place from the north as well as from the west. In addition, these considerations still suffer from two major deficiencies: lack of sufficient knowledge of the phylogenetic relationships within the Parastenocarididae, and existence of large gaps in the recording of the occurrence of this family in many parts of the world.

\section{BATHYNELLACEA}

The Bathynellacea seem to provide better opportunity for formulating hypotheses. At least within the family Parabathynellidae, the phylogenetic relationships of its genera are better known. From these I concluded (Schminke, 1973, 1974) that the Australian genera are part of one of two independent lines along which the Parabathynellidae were believed to have dispersed from their center of origin in east Asia, where the most primitive species occur. Along both lines, the genera become more and more apomorphic in their characters. One line was assumed to have led west via Europe and Africa to South America, the other south via Australia to South America.

Because of the very poor dispersive capacity of the Bathynellacea (Schminke, 1974), dispersal from Asia to Australia could not have taken place unless land connections had existed between Asia an Australia at a time that would not only have enabled the Parabathynellidae to subsequently reach New Zealand but also to extend their range to South America via Antarctica. A constellation of the landmasses in the southern hemisphere which would have allowed this sequence of events does not seem to have existed, if the latest reconstructions of the earth's history are correct. This need not concern us too much since not in seeking mere coincidences between distributional patterns and geological constellations, viz. by simultaneously taking into account biological as well as geological evidence, can zoogeographical studies provide significant contributions to the reconstruction of the earth's history. Zoogeographical studies can contribute to it only in tracing causal relationships by independently applying their own genuine methodology (Müller, 1974). This may result, as in the present case, in contradictions with evidence from other sources. When this happens, it does not mean that the reconstructions of phylogenetic relationships underlying the zoogeographical conclusions must by necessity be false. However, as a potential source of falsification, such contradictions invite reconsideration of the phylogenetic analysis.

The weak points, then, in reconstructing the phylogenetic relationships within the family Parabathynellidae obviously are those presumed to exist between the Malaysian genus Batubathynella and some of the Australian ge- 
nera because of great similarities in the complicated structure of the male thoracopods VIII. Reexamination of abundant new material of the genus $B a$ tubathynella (leg. Fernando), which was in far better condition than the specimen available for the earlier study, showed that the picture gained from that specimen could not be substantiated. Independent evidence suggesting that these presumed relationships were probably due to misinterpretations came from a study of South African Bathynellacea (Schminke, unpubl.). If the hypothesis of a double armed dispersion of the Parabathynellidae from a center of origin in east Asia were correct, there should have been no overlap in South Africa of representatives of the genera characteristic for the two independent routes of dispersal leading up to South America. Such an overlap, however, does in fact occur. What, then, could an alternative look like?

\section{PERSPECTIVES}

Debate in historical zoogeography lately has centered around what has been called the dispersal and vicariance paradigms (Platnick and Nelson, 1978). The vicariance model requires an ancestral species which enlarges its initially small area of distribution. This initial primary dispersal, which in the extreme may lead to cosmopolitanism, takes place in the absence of a barrier. Subsequent geological or other events may result in fragmentation of this area into two isolated ones by the appearance of a barrier, and in differentiation of the then isolated populations into two allopatric species. Subsequent fragmentations of the areas of these species, followed by further speciation events, could lead, without any further dispersal, to a worldwide pattern of distribution which in most groups is usually complicated by events of secondary dispersal indicated in the recent fauna by sympatry.

The dispersal model, on the other hand, differs from the vicariance model in the relative age of disjunctions and barriers. According to this model, an ancestral species extends its range by dispersal across a preexisting barrier, resulting in immediate isolation and disjunction of its offshoot. Disjunction and barrier are of different ages, the latter being older, whereas, according to the vicariance model, both are the same age. For a more detailed treatment of this theoretical background, the reader should see discussions in Ball (1975, 1977), Croizat et al. (1974), and Platnick and Nelson (1978).

Schram (1977) recently suggested that the worldwide pattern of distribution of the Bathynellacea may probably be better understood in terms of vicariance rather than a classic dispersal model such as the one I have propounded. As pointed out by Platnick and Nelson (1978), many alleged dispersal hypotheses are in reality what they call vicariance models in disguise. These are not really dispersal models because the postulated dispersal is supposed to have taken place "prior to the appearance of the barrier and prior to the fragmentation of the range of the ancestral species" (p. 2). My "dispersal" model of bathynellacean distribution falls under this heading. If we look at the distribution ranges of the parabathynellid genera with this in mind (fig. 1), Schram's view becomes easily understandable. All intrageneric con- 


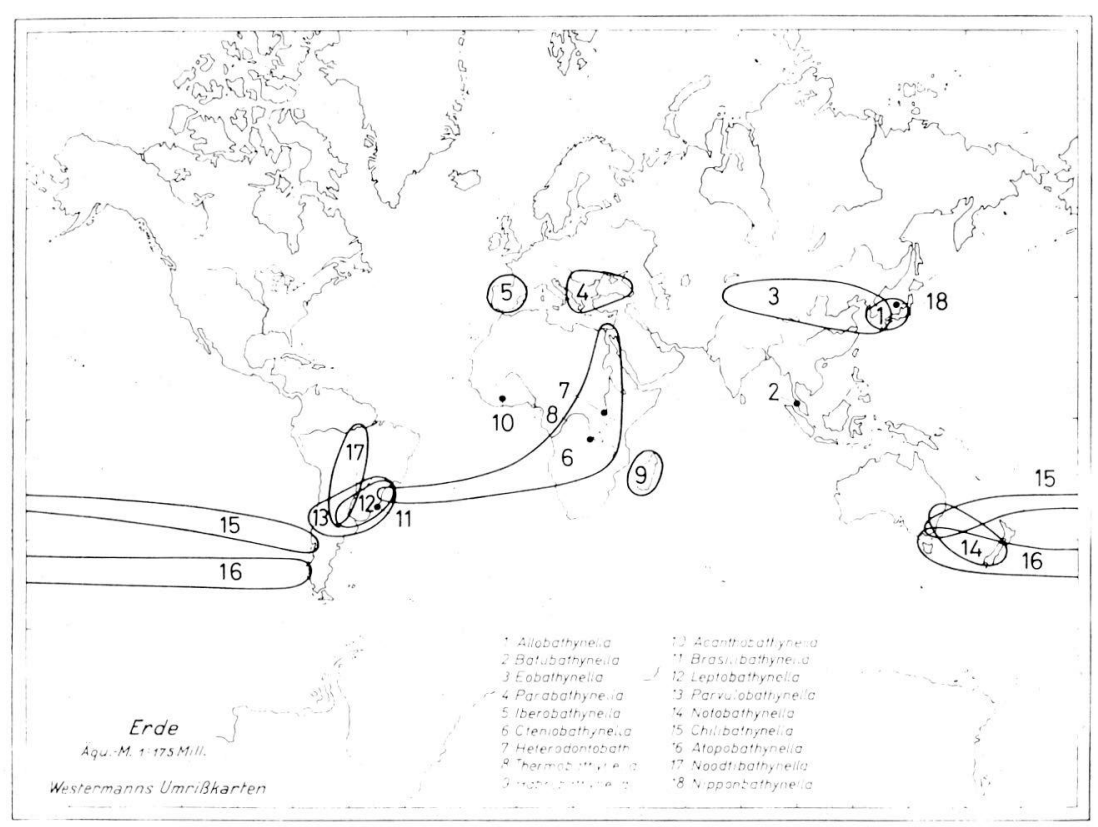

Fig. 1. Distribution of the genera of the family Parabathynellidae (without genus Hexabathynella). (After Schminke, 1973.)

nections run east-west, and even the intergeneric ones never run north-south except for the case that has turned out to be untenable. This picture will become even more pronounced when my records of the genera Chilibathynella and Leptobathynella from Africa, Atopobathynella from Madagascar, and Iberobathynella from North America appear in print.

Bathynellacea, then, appears to belong to those groups of organisms which reached a cosmopolitan distribution prior to the breakup of Pangaea, and whose zoogeography can now be understood only in terms of vicariance and secondary dispersal. If this is true, phylogenetic studies should result in the distinction of two monophyletic groups within the Parabathynellidae, a northern or laurasian group and a southern or gondwanian one.

It is not yet clear which explanation best fits the distribution of Parastenocarididae. The depauperate Australian fauna and the apparent ability of this family to spread over longer distances suggest that their zoogeography may probably be best explained in terms of a primary dispersal history. Their phylogenetic age also appears to point in this direction. An origin in the early Tertiary, or even somewhat earlier, has tentatively been suggested for this family (Noodt, 1969).

The Bathynellacea, in comparison, are decidedly older, circumstantial evidence pointing to an origin as far back as the Carboniferous. They are old 
enough to have been subject to all consequences of the breakup of Pangaea, the sequence of their phylogenetic branchings probably being a mirror, to some extent, of the sequence of geological changes. The Parastenocarididae, on the other hand, are not likely to have witnessed directly, to their full, the repercussions of continental disruption. They had to achieve post festum what the Bathynellacea had reached before: a worldwide distribution. Thus, the history of both groups is apt to cast some light on how the continents evolved. Each, however, does it from a different direction, and it is this double aspect that makes it worthwhile to pick just these two groups among interstitial Crustacea for studies with emphasis on problems of historical zoogeography.

\section{ACKNOWLEDGEMENTS}

Grants which enabled me to collect the material referred to in this study were provided by the following organizations: Deutscher Akademischer Austauschdienst, Fritz-Thyssen-Stiftung, Deutsche Forschungsgemeinschaft. I thank Prof. Dr. C.H. Fernando, University of Waterloo, Canada, for the gift of several specimens of Batubathynella malaya. Dr. T. Gledhill, Wareham, England, was so kind to help with my English.

\section{ZUSAMMENFASSUNG}

Es werden Aspekte erörtert, die sich im Verlauf meiner neuesten Untersuchungen zur Zoogeographie der Bathynellacea und Parastenocarididae ergeben haben. Die Parastenocarididae Australiens fallen durch seltenes Vorkommen und geringe Artenzahl auf. Die Ausbeute einer ausgedehnten Sammelreise durch Australien im Jahr 1968 bestand aus nur 4 Arten, die 3 Gattungen angehören. Trotz verwandtschaftlicher Beziehungen zu Arten von anderen gondwanischen Kontinenten legen die Artenarmut der Familie in Australien und ihre vermutliche Fähigkeit zu weiträumiger Ausbreitung eine späte Ankunft in Australien nahe. Di Besiedlung dieses Kontinents fand höchstwahrscheinlich aus 2 verschiedenen Richtungen statt. Hinsichtlich der Bathynellacea haben sich vermutete Verwandtschaftsbeziehungen zwischen Gattungen der Familie Parabathynellidae aus Malaysia und Australien nicht bestätigt. Alternativ zu dem früher vertretenen, zweiarmigen Verbreitungsmodell der Parabathynellidae wird im Anschluß an Schram (1977) die Möglichkeit eines Vikarianzmodells erörtert. Die Zoogeographie der Parastenocarididae ist wahrscheinlich am besten durch ein Modell primärer Ausbreitung zu erklären.

\section{LITERATURE}

BALL, I. 1975. Nature and formulation of biogeographical hypotheses. Syst. Zool. 24: 407-430. BALL, I. 1977. On the phylogenetic classification of aquatic planarians. Acta Zool. Fenri. 154: 21-35.

CHAPPUIS, P.A. 1931. Copepoda Harpacticoida der Deutschen Limnologischen SundaExpedition. Arch. Hydrobiol., Suppl. 8: 512-584.

CROIZAT, L., NELSON, G. and D.E. ROSEN 1974. Centers of origin and related concepts. Syst. Zool. 23: 265-287.

ENCKELL, P.H. 1969. Distribution and dispersal of Parastenocarididae (Copepoda) in northern Europe. Oikos 20: 493-507.

ENCKELL, P.H. 1970. Parastenocarididae (Copepoda Harpacticoida) from Ceylon. Ark. Zool., Ser. 2, 22 (13): 545-556.

KULHAVY, V. and W. NOODT. 1968. Über Copepoden (Crustacea) aus dem limnischen Mesopsammal Islands. Gewäss. Abwäss. 46: 50-61.

MÜLlER, P. 1974. Aspects of zoogeography. Dr. W. Junk bv Publishers, The Hague.

NOODT, W. 1969. Die Grundwasserfauna Südamerikas, in: Biogeography and ecology in South 
America, FitTkAU E.J., ILliES J., KLINGE H., SCHWABE G.H., and SiOLI H., Eds., Dr. W. Junk N.V., The Hague, Tome 2: 659-684.

PLATNICK, N.I., and G. NELSON, 1978. A method of analysis for historical biogeography. Syst. Zool. 27:1-16.

SCHMINKE, H.K. 1971. Zwei neue Parastenocaris-Arten (Copepoda, Harpacticoidea) von Tenerife (Kanarische Inseln). Gewäss. Abwäss. 50/51: 66-75.

SCHMINKE, H.K. 1973. Evolution, System und Verbreitungsgeschichte der Familie Parabathynellidae (Bathynellacea, Malacostraca). Akad. Wiss. Lit. Mainz, Math.-nat. Kl., Mikrofauna Meeresboden 24:1-192.

SCHMINKE, H.K. 1974. Mesozoic intercontinental relationships as evidenced by bathynellid Crustacea (Syncarida: Malacostraca). Syst. Zool. 23:157-164.

SCHRAM, F.R. 1977. Paleozoogeography of the late Paleozoic and Triassic Malacostraca. Syst. Zool. 26:367-379. 